\title{
Prevalence of, and Factors Influencing First Line Antiretroviral Treatment Failure among Adult HIV Patients at Antiretroviral Treatment Clinic of Mettu Karl Referral Hospital, South Western, Ethiopia: A Prospective Cross Sectional Study, 2021
}

\author{
Gudisa Bereda ${ }^{1^{*}}$ and Gemechis Bereda ${ }^{2}$ \\ ${ }^{1}$ SWAN diagnostic pharmaceutical importer, Addis Ababa, Ethiopia \\ ${ }^{2}$ Awash Bank, Addis Ababa, Ethiopia
}

*Corresponding author: Gudisa Bereda, SWAN diagnostic pharmaceutical importer, Addis Ababa, Ethiopia, Tel:+251919622717, E-mail: gudisabareda95@gmail.com

\begin{abstract}
Background: Antiretroviral treatment failure is defined as progression of disease and high risk of mortality after beginning of highly active anti-retroviral therapy. First-line ART failure has emerged as a growing concern. ART failure is a major challenge to HIVIAIDS management in resource-limited settings including Ethiopia where the diagnosis and management of ART failure is a key problem. Principal factors involving fist-line antiretroviral regimen failure include poor adherence to medication, younger age, lower baseline CD4+ count and higher baseline viral load.
\end{abstract}

Objective: To ascertain prevalence, and factors influencing first line anti-retroviral treatment failure among human immunodeficiency patients at anti-retroviral treatment clinic of Mettu Karl Referral Hospital.

Methods: An institutional based prospective cross sectional study design was conducted from April 03/2021 to June 04/2021. Data was collected through employing check list and semi-structured questioner, and then the collected data was coded and analyzed by statistical packages for social sciences 25.0 version statistical software. Both bi-variable and multivariable analysis performed to determine the association between outcome and predictors variables. In the multiple logistic regression models significant association was declared at $p$-value $<0.05$.

Results: The magnitude of first line anti-retroviral treatment failure among human immunodeficiency patients was $29.3 \%$.At the time of study almost half of patients, $55(41.4 \%)$ were married and $85(63.9 \%)$ were living in urban. Age $\geq 42$ years (AOR: $2.04 ; 95 \% \mathrm{Cl}: 1.0761-5.902 ; \mathrm{P}=0.002$ ), rural residents (AOR: 3.51; 95\% Cl:1.1.951-11.4 30; $\mathrm{P}=0.001$ ), divorced (AOR:1.962; 95\%Cl:0.427-2.942; $\mathrm{P}=0.008$ ), AZT $+3 T C+$ NVP at initial ARV regimen follow up (AOR:2.980; $95 \% \mathrm{Cl}: 1.1842-1.749 ; \mathrm{P}=0.006)$, duration of $\mathrm{ARV}$ treatment $\geq 6$ years (AOR:3.15; 95\%Cl: 2.963-7.028; $\mathrm{P}=0.006$ ), and base line WHO clinical stages III/IV (AOR:3.97; 95\% Cl:1.045$14.937 ; P=0.009$ ) were predictors of first line anti-retroviral treatment failure among HIV patients at ART clinic.

Conclusion and recommendation: The magnitude of first line anti-retroviral treatment failure among HIV patients was high. The initial regimen for HIVIAIDS infected patients were $\mathrm{D} 4+3 \mathrm{TC}+\mathrm{EFV}$. Age greater than forty two years, rural residents, divorced, AZT + 3TC + NVP at initial ARV regimen follow up, duration of ARV treatment $\geq 6$ years and base line WHO clinical stages III/IV were the factors associated with $1^{\text {st }}$ line ART failure. Health care workers should have to educate the patients on how the disease where prevented and controlled and government also implement new drafts on the drug efficiency.

\section{Keywords}

$1^{\text {st }}$ line ART Failure, Prevalence, Influencing Factors, ART Clinic, Mettu Karl Referral Hospital, Ethiopia
Abbreviations
ART: Anti-retroviral Therapy; ARV: Antiretroviral; TB: Tu- berculosis; cART: Combination Antiretroviral Therapy; CD4: Cluster of Differentiation 4; HAART: Highly Active Antiretroviral therapy; HIVIAIDS: Human Immune Virus/ Acquired Immune Deficiency Syndrome; PLWH: People Were Living with HIV Infection; SSA: Sub-Saharan Africa; UNAIDS: Joint United Nations on HIVIAIDS; WHO: World Health Organization

Citation: Bereda G, Bereda G (2021) Prevalence of, and Factors Influencing First Line Antiretroviral Treatment Failure among Adult HIV Patients at Antiretroviral Treatment Clinic of Mettu Karl Referral Hospital, South Western, Ethiopia: A Prospective Cross Sectional Study, 2021. Int J Virol AIDS 8:075. doi.org/10.23937/2469-567X/1510075

Accepted: July 26, 2021: Published: July 28, 2021

Copyright: (c) 2021 Bereda G, et al. This is an open-access article distributed under the terms of the Creative Commons Attribution License, which permits unrestricted use, distribution, and reproduction in any medium, provided the original author and source are credited. 


\section{Introduction}

Human immunodeficiency virus is responsible for a worldwide pandemic, and it is the cause of acquired immune deficiency syndrome (AIDS). All HIV-infected adults and adolescents started ART when their CD4 count was $<500$ cells $/ \mathrm{mm}^{3}$ irrespective of the World Health Organization (WHO) clinical stage, WHO clinical stages 3 and 4 irrespective of CD4 cell count, active tuberculosis disease irrespective of CD4 cell count, all HIV positive pregnant and breastfeeding women irrespective of CD4 count and all HIV-infected partners of sera-discordant couple regardless of CD4 cell count (to reduce the risk of HIV transmission to the negative partner). First-line ART regimen is recommended, which is simplified and less toxic, and more convenient regimens as fixed-dose combinations are available. Preferred first Line regimens drugs are TDF + 3TC + EFV (FDC) while Alternative regimen are AZT + 3TC + EFV, $A Z T+3 T C+N V P$ and TDF + 3TC + NVP [1]. Treatment failure occurs when a combination of the ARV regimen fails to control HIV infection. This could be virologic, immunologic and/or clinical failure [2]. Antiretroviral (ARV) treatment failure is defined as progression of disease and high risk of mortality after beginning of HAART. It can be assessed by clinical failure (occurrence of new infections (OI) or malignancy, symptomatic of clinical disease progression; recurrence of previous $\mathrm{OI}$, onset, or recurrence of WHO stage IV ( \& certain stage III) conditions, etc.), immunologic failure (a decline in the CD4 + T cell count), or virological failure (The inability to maintain suppression of viral replication to an HIV RNA level < 1000) either in combination or discordantly. Clinical and immunologic criteria have been used for assessing treatment failure in the absence of viral load (VL) test $[3,4]$. The patients who had failed for fist-line drug are $46 \%$ more likely to fail again for second-line drugs and are attributed to the higher number of side effects and have greater likelihood of experiencing drug resistance and treatment fatigue as a result of being on treatment longer [5]. Previous studies reported that various factors including being male gender, illiterate, widower, poor adherence and treatment interruption, WHO clinical stage III and/or IV, low CD4 cell at ART initiation, presence opportunistic infections, low $B M I$, taking ARV regimen before ART initiation, taking Stavudine and Zidovudine (AZT) based regimen, TB coinfection, substance use and longer duration on ART were significantly associated with first line ART failure [6]. The World Health Organization cites poor access to services, complex drug regimens, pregnancy, mental health disorders, substance abuse, and weak social support as major barriers to adherence [7]. Globally, it is estimated that 36.9 million people were living with HIV during 2017. Sub-Saharan Africa (SSA) remains significantly affected, accounting for $69.5 \%$ of the people living with HIV (PLWHA). Ethiopia is among the SSA countries most affected by HIV/AIDS with an estimated 710,000 people living with HIV in 2016 [8]. The introduction of highly active anti-retroviral therapy was a critical milestone in the history of HIV disease resulting in a dramatic reduction of morbidity and mortality, and improvement in the quality of life of PLWHA [9]. In the sub-Saharan Africa, many patients who experience virological failure do not switch to potent second line regimens due to re-source limitation, yet those who remain on a failing first-line regimen experience dis proportionately higher morbidity and mortality compared to those who switch [10]. Sub-Saharan Africa is a region highly affected by HIV epidemic. Ethiopia is one of the Sub-Saharan African countries with the highest numbers of people affected by the problem [8]. In Ethiopia, there were 710,000 patients infected with HIV/AIDS in 2016. Around 404,405 HIV patients were on an antiretroviral therapy (ART) and around 20,000 AIDS-related deaths were reported in the same year [11]. In Ethiopia, viral load determination and guiding ART treatment with the gold standard test (viral load) has started recently because of resource limitation. Consequently, there is limited data on treatment failure and its associated risk factor. The available studies [12] were conducted on first-line antiretroviral treatment failure. These studies didn't address second-line and immunovirological discordance of treatment failure Studies in East Africa have shown a high prevalence of immunologic failure ranging from $8 \%$ to $57 \%$ among clients on first-line HAART, and furthermore, the magnitude increases as the time of follow-up increases [13]. The prevalence of first-line ART failure differs significantly across countries depending on the criteria (clinical, immunological or virologic) used for its diagnosis. The viral load cut-off points to diagnose treatment failure also vary in different countries. The first-line ART virologic failure rate in Africa was 7.1 per 100 patient years of follow-up [14]. In Ethiopia, studies reported virologic failure rates ranging from 5.3 to $19 \%$ [15], and the percentage of patients switched to secondline ART was $1.5 \%$ in 2013 [16]. This study were identify the risk factors associated with first-line ART failure and increase the treatment efficacy that permit better use of these potent drugs by, avoiding unnecessary side effects of first-line drug, prevent drug resistance, and decrease economic burden, especially in a resourcelimited setting like Ethiopia.

\section{Methodology}

\section{Study design, area and subject}

An institutional-based prospective cross sectional study was conducted from April 03/2021 to June 04/2021 in MKRH, Oromia Regional State; Southwestern, Ethiopia, located at $600 \mathrm{~km}$ from Addis Ababa. The study population of our study was all HIV-infected adult patients who were taking ART during the study period at study area. Those who had been on ART for $\geq 6$ months, those who had documented CD4 cell count, those who had viral load measurement at baseline and 6 months 
were included in the study. Who had pregnancy and breastfeeding history the past 6 months while on treatment, at 6 months' visit or had missing values of CD4 cell count, viral load at baseline and 6 months' visit, patients who were switched to $2^{\text {nd }}$ line as a result of side effects to antiretroviral drugs in $1^{\text {st }}$ line treatment were excluded.

\section{Sample size calculation and sampling technique}

The sample size was determined by using the single population proportion formula: The sample size was determined based on " $P$ " value which was taken from Harar public hospitals, Eastern Ethiopia, $\mathrm{P}=0.21$, or $21 \%$. $n=\frac{(z a / 2) 2 p(1-p)}{d 2}, \mathrm{n}=$ sample size, $\mathrm{P}=$ prevalence of $1^{\text {st }}$ line ART failure, $d=$ margin of sampling error tolerated, $\mathrm{z}=$ the standard normal value at confidence interval of $95 \% . \mathrm{n}=n=\frac{(1.96)^{2}(1-0.21) \times(0.21)}{(0.05)^{2}}=255$. Since the total number of first line ART failure patients medical record cards from January 2021 to March 2021 was less than 10,000, which was 229 reduction formula (correction formula) was applied as follow; $n_{f}=$ $\mathrm{n} /(1+(\mathrm{n} / \mathrm{N})), \mathrm{n}_{\mathrm{f}}=255 /(1+(255 / 229)=121$. When $10 \%$ contingency is added to minimize non response rate, then final sample size was found to be 133 . A systematic random sampling technique was applied to select the patients $1^{\text {st }}$ line ART failure by determining the sampling interval. Sampling interval was calculated by $(K=N / n)$, then $K=229 / 133=1.7^{\text {th } ~} 2^{\text {th }}$. Then, the first patients $1^{\text {st }}$ line ART failure was selected by the lottery method from the $1^{\text {st }}$ line ART failure patients.

\section{Variables}

The outcome variable for this study was the occurrence of $1^{\text {st }}$ line ART failure, and the predictors was socio demographic factors (age, sex, educational status, monthly income, marital status, family size), and clinical characteristics (adherence, advanced WHO stage, CD4 count, regimen change, function al status, co-infection and disclosure).

\section{Measurements}

A well-structured standard checklist and questionnaire was used to collect relevant information from patient face to face and their charts. Data was extracted from all eligible patient medical charts and patients' response. The data collection tool contains patient socio-demography, the question was having five parts that are socio- demographic characteristics, clinical characteristics of patients, laboratory measures and ART treatment related conditions, health facilities related questions and behaviors of HIV/AIDS patients those who were on ART. All the data collection process was conducted by recruited nurses and monitored by the $\mathrm{PI}$ at the hospital. Treatment failure was defined according to World Health Organization (WHO) 2010 criteria by at least 1 of the following in a patient taking 2 NRTIs and 1 NNRTI for 1 year or more:1) New WHO clinical stage 3 or 4 disease (with CD4 count $<200$ cells $/ \mathrm{mm}^{3}$ and viral load $>400$ copies $/ \mathrm{ml}$ ); 2) CD4 count of $<100$ cells $/ \mathrm{mm}^{3}$ at 12 months of treatment $\mathrm{OR}$ a fall to baseline (nadir) or below baseline CD4 count OR a $50 \%$ fall from ontreatment peak value; 3) A viral load $>5000$ copies/ $\mathrm{ml}$. The $1^{\text {st }}$ line ART non-adherence was measured by patient self-report based on pills count. This adherence has three categories that is poor adherence $(<85 \%)$ if the patient miss to take less than 6 of 30 prescribed doses or $>9$ doses of 60 prescribed dose, fair adherence (85-94\%) if the patient miss to take 3-5 of 30 prescribed doses or 3-9 doses of 60 prescribed dose and good adherence (>90\%) if the patient miss to take $\leq 2$ of 30 prescribed doses or $\leq 3$ doses of 60 prescribed dose [1]. In order to assure quality of data important measures were undertaken including: the patient card number was used, to check for if there is invalid and incomplete pertinent response and these cards were also coded so over or under count was not matter. The data collected was checked for completeness and consistency on daily basis.

\section{Data analysis}

The screened data was coded and analyzed through employing statistical packages of social sciences version 25.0 statistical Software. Categorical variables were expressed by percentage and frequency. Bi-variate and multivariate logistic regression analyses were conducted to determine associated risk factors of $1^{\text {st }}$ line ART failure. Variables with a $p$-value of $<0.25$ on bivariate analyses were selected for multivariate logistic regression analysis to identify independent risk factors of $1^{\text {st }}$ line ART failure. Variables having a P-value $\leq 0.05$ on the final model of multivariate logistic regression were considered as significantly associated risk factors for $1^{\text {st }}$ line ART failure.

\section{Operational Definitions}

ARV treatment failure is progression of disease and high risk of mortality after beginning highly active antiretroviral therapy [1].

Clinical failure New or recurrent WHO clinical stage 4 conditions, or new or recurrent WHO stage 3 with pulmonary TB or severe bacterial infections [17].

Good adherence was defied as patients taking antiretroviral drug on time, regularly $\geq 95 \%$, while < $95 \%$ was categorized as poor adherence [18].

\section{Results}

\section{Socio-demographic characteristics and socio- economic condition}

A total of 133 HIV/AIDS patients who received ART were enrolled in the study. Of these, $79(59.4 \%)$ of them were male and $54(40.6 \%)$ were female. One-third 
Table 1: Socio-demographic characteristics and socio-economic condition of the patients attending ART clinic at MKRH, 2021 $(\mathrm{n}=133)$.

\begin{tabular}{|c|c|c|c|}
\hline Variables & Category & Frequency & Percent \\
\hline \multirow[t]{4}{*}{ Age } & $15-29$ years & 42 & 31.6 \\
\hline & $30-35$ years & 43 & 32.3 \\
\hline & $36-41$ years & 30 & 22.6 \\
\hline & $\geq 42$ years & 18 & 13.5 \\
\hline \multirow[t]{2}{*}{ Sex } & Male & 79 & 59.4 \\
\hline & Female & 54 & 40.6 \\
\hline \multirow[t]{2}{*}{ Residency } & Urban & 85 & 63.9 \\
\hline & Rural & 48 & 36.1 \\
\hline \multirow[t]{2}{*}{ Income(ETB) } & $<1500$ & 103 & 77.4 \\
\hline & $\geq 1500$ & 30 & 22.6 \\
\hline \multirow[t]{4}{*}{ Marital status } & Single & 55 & 41.4 \\
\hline & Married & 32 & 24.1 \\
\hline & Divorced & 37 & 27.8 \\
\hline & Widowed & 9 & 6.8 \\
\hline \multirow[t]{5}{*}{ Educational status } & Unable to read and write & 61 & 45.9 \\
\hline & Grade 1-8 & 40 & 30.1 \\
\hline & Grade 9-12 & 17 & 12.8 \\
\hline & Diploma & 12 & 9.0 \\
\hline & Degree, and above & 3 & 2.3 \\
\hline \multirow[t]{4}{*}{ Living condition } & Alone in house & 62 & 46.6 \\
\hline & Alone in street & 9 & 6.8 \\
\hline & With family/friend & 48 & 36.1 \\
\hline & Others & 14 & 10.5 \\
\hline \multirow[t]{2}{*}{ Magnitude of $1^{\text {st }}$ line ART failure } & Yes & 39 & 29.3 \\
\hline & No & 94 & 70.7 \\
\hline
\end{tabular}

Table 2: Clinical characteristics of the patients attending ART clinic at MKRH, $2021(n=133)$.

\begin{tabular}{|l|l|l|l|}
\hline Variables & Category & Frequency & Percent \\
\hline Functional status & Working & 103 & 77.4 \\
\hline & Not working & & 22.6 \\
\hline WHO stage of HIV & & 24 & 18.0 \\
& Stage I & 67 & 50.4 \\
\hline Body mass index & Stage II & 42 & 31.6 \\
& Stage III/IV & & \\
\hline & & 36 & 27.1 \\
\hline Opportunistic infection & $\leq 16 \mathrm{~kg} / \mathrm{m}^{2}$ & 72 & 54.1 \\
& $16.01-18.5 \mathrm{~kg} / \mathrm{m}^{2}$ & 25 & 18.8 \\
\hline Ol after initiate ART & $>18.5 \mathrm{~kg} / \mathrm{m}^{2}$ & 79 & 59.4 \\
& Yes & 54 & 40.6 \\
\hline
\end{tabular}




\begin{tabular}{|c|c|c|c|}
\hline \multirow[t]{2}{*}{ TB co infection } & Yes & 73 & 54.9 \\
\hline & No & 60 & 45.1 \\
\hline \multirow{2}{*}{$\begin{array}{l}\text { Chronic non communicable diseases during on first line } \\
\text { ART }\end{array}$} & Yes & 67 & 50.4 \\
\hline & NO & 66 & 49.6 \\
\hline \multirow[t]{2}{*}{ Presence of malnutrition during on first line ART } & Yes & 36 & 27.1 \\
\hline & No & 97 & 72.9 \\
\hline \multirow[t]{2}{*}{ Cotrimoxazole taken } & Yes & 90 & 67.7 \\
\hline & No & 43 & 32.3 \\
\hline
\end{tabular}

$43(32.3 \%)$ of the patients were within the age group of $30-35$ years. The majority of $103(77.4 \%)$ respondents were earned monthly income $<1500$ ETB. At the time of study almost half 55(41.4\%) of patients were married and $85(63.9 \%)$ were living in urban. Slightly less than half $63(45.9 \%)$ of participants educational status were unable to read and write, and majority $62(46.6 \%)$ of patients dwell alone in the house. The magnitude of first line anti-retroviral treatment failure among HIV patients was $29.3 \%$ (Table 1 ).

\section{Clinical characteristics of the patients}

Preponderance $103(77.4 \%)$ of respondents were working and half $67(50.4 \%)$ of respondents HIV/AIDS clinical WHO stage was Stage II. Majority 72(54.1\%) of participants body mass index were between 16.0118.5 range, and $79(59.4 \%)$ patients had opportunistic infection. Above half $85(63.9 \%)$ of participants hadn't Ol after initiate ART. Majority $73(54.9 \%)$ of patients had TB co infection, and half $67(50.4 \%)$ patients were have chronic non communicable diseases during on first line ART. Only less than one-third $36(27.1 \%)$ of respondents had have presence of malnutrition during on first line ART, and majority 90(67.7\%) patients were take cotrimoxazole (Table 2).

\section{Treatment related factors of patients}

The initial regimen for HIV/AIDS infected patients were $\mathrm{D} 4 \mathrm{~T}+3 \mathrm{TC}+\mathrm{EFV}$ (1b) 55 (41.0\%), and majority $67(60.4 \%)$ of patients were substitute the medication none. Side effects $59(44.4 \%)$ were the major reason that why the patients substitute their regimen. Half $67(50.4 \%)$ of patients adherence status were fair, and $67(50.4 \%)$ were keeping appointment schedule through came on time. Slightly less than half $73(54.9 \%)$ of respondents weren't have diagnosis of recurrent pneumonia (> 2 episodes), and $72(54.1 \%)$ of patients diagnosed not to have antiretroviral treatment failure (Table 3).

\section{Multi-variate logistic regression of treatment failure among 1st line ART failure}

All variables showing a P-value of less than 0.25 in uni-variate analysis were further tested in the multivariate logistic regression models, on the final model of multivariate logistic regression. Prevalence of first line anti-retroviral treatment failure among HIV patients was highest among patient $\geq 42$ years were (AOR: 2.04; 95\%Cl: 1.0761-5.902; $\mathrm{P}=0.002$ ) 2 times more likely develop treatment failure than other age category. ART users who dwelled in rural areas were two times more likely to develop first-line ART failure than those reside in urban (AOR: 3.51; 95\% Cl: 1-11.430; $\mathrm{P}=$ 0.001 ) 3.5 times more likely develop treatment failure than those in lived in urban. Regarding marital status divorced (AOR: 1.962; 95\% $\mathrm{Cl}$ : 0.427-2.942; $\mathrm{P}=0.008$ ) 2.9 times more likely develop treatment failure than the left marital status. HIV/AIDS infected patients who were on AZT + 3TC+NVP (1c) at initial ARV regimen follow up (AOR: 2.980; 95\%Cl: 1.1842-1.749; $\mathrm{P}=0.006$ ) 3 times more likely develop treatment failure than those who taken others regimen. Patients whose baseline WHO clinical stages III/IV (AOR: 3.97; 95\%Cl: 1.045-14.937; P $=0.009$ ) were 3.9 times more likely develop treatment failure than baseline WHO clinical stage I and II and patients whose duration of ARV treatment $\geq 6$ years (AOR: 3.15; 95\%Cl: 2.963-7.028; $\mathrm{P}=0.006$ ) were 3.15 times more likely develop treatment failure than those who had duration of ARV treatment $<6$ years (Table 4 ).

\section{Discussion}

Treatment failure is one of the causes of mortality and development of drug resistant viral strains potentate a significant challenge globally $[19,20]$. Sustainable treatment failure is related to difficulty to delivering quality care, the emergence of drug resistant viruses which limits the treatment option and increases the threat of morbidity and mortality. The identification and management of first-line ART failure is a key challenge for HIV programs in resource-limited setting. Staying on a failing first-line therapy is associated with an increased risk of mortality [21].

The present study revealed, the magnitude of first-line ART treatment failure was $29.3 \%$. This study was higher than the survey conducted in Harar public hospitals 21\%, Asella Referral Hospital 27\% [22,23]. The difference was more respondents in recent survey was due-to poor patient-health care workers, no adequate education and counseling about the disease, limited access to ART as 
Table 3: Treatment related factors of patients attending ART clinic at MKRH, $2021(n=133)$.

\begin{tabular}{|c|c|c|c|}
\hline Variables & Category & Frequency & Percent \\
\hline Initial ARV regimen & $\begin{array}{l}D 4 T+3 T C+N V P(1 a) \\
D 4 T+3 T C+E F V(1 b) \\
A Z T+3 T C+N V P(1 c) \\
A Z T+3 T C+E F V(1 d) \\
\text { Others }\end{array}$ & $\begin{array}{l}36 \\
55 \\
28 \\
9 \\
6\end{array}$ & $\begin{array}{l}26.9 \\
41.0 \\
20.9 \\
6.7 \\
4.5\end{array}$ \\
\hline Duration of ARV treatment & $\begin{array}{l}<6 \text { years } \\
\geq 6 \text { years }\end{array}$ & $\begin{array}{l}47 \\
86\end{array}$ & $\begin{array}{l}35.3 \\
64.7\end{array}$ \\
\hline Number of drug substitutions made & $\begin{array}{l}\text { None } \\
\text { Once } \\
\text { Twice or more }\end{array}$ & $\begin{array}{l}67 \\
60 \\
6\end{array}$ & $\begin{array}{l}60.4 \\
45.1 \\
4.5\end{array}$ \\
\hline Reason for drug substitution & $\begin{array}{l}\text { Side effects } \\
\text { Risk of pregnancy } \\
\text { Due to new Tuberculosis } \\
\text { New drug available } \\
\text { Drug stock out } \\
\text { Others }\end{array}$ & $\begin{array}{l}59 \\
24 \\
14 \\
6 \\
18 \\
12\end{array}$ & $\begin{array}{l}44.4 \\
18.0 \\
10.5 \\
4.5 \\
13.5 \\
9.0\end{array}$ \\
\hline Adherence status & $\begin{array}{l}\text { Good } \\
\text { Fair } \\
\text { Poor }\end{array}$ & $\begin{array}{l}36 \\
67 \\
30\end{array}$ & $\begin{array}{l}27.1 \\
50.4 \\
22.6\end{array}$ \\
\hline Keeping appointment schedule & $\begin{array}{l}\text { Came on time } \\
\text { Came late } \\
\text { Came early }\end{array}$ & $\begin{array}{l}67 \\
30 \\
36\end{array}$ & $\begin{array}{l}50.4 \\
22.6 \\
27.1\end{array}$ \\
\hline $\begin{array}{l}\text { Diagnosis of recurrent pneumonia } \\
\text { (> } 2 \text { episodes) }\end{array}$ & $\begin{array}{l}\text { Yes } \\
\text { No }\end{array}$ & $\begin{array}{l}60 \\
73\end{array}$ & $\begin{array}{l}45.1 \\
54.9\end{array}$ \\
\hline $\begin{array}{l}\text { Diagnosed to have antiretroviral treatment } \\
\text { failure }\end{array}$ & $\begin{array}{l}\text { Yes } \\
\text { No }\end{array}$ & $\begin{array}{l}61 \\
72\end{array}$ & $\begin{array}{l}45.9 \\
54.1\end{array}$ \\
\hline
\end{tabular}

Table 4: Multi-variate logistic regression of treatment failure among patients attending ART clinic at MKRH, $2021(n=133)$.

\begin{tabular}{|c|c|c|c|c|c|}
\hline Variables & Category & n (\%) & COR $(95 \% \mathrm{Cl})$ & AOR (95\% C.I) & p-value \\
\hline Age & $\begin{array}{l}15-29 \text { years } \\
30-35 \text { years } \\
36-41 \text { years } \\
\geq 42 \text { years }\end{array}$ & $\begin{array}{l}42(31.6) \\
43(32.3) \\
30(22.6) \\
18(13.5)\end{array}$ & $\begin{array}{l}\text { Ref } \\
0.243(0.195-2.830) \\
0.947(0.690-3.864) \\
1.053(0.867-9.142)\end{array}$ & $\begin{array}{l}\text { Ref } \\
0.675(1.823-1.724) \\
1.021(0.047-1.439) \\
2.04(1.0761-5.902)\end{array}$ & $\begin{array}{l}0.179 \\
0.674 \\
0.002\end{array}$ \\
\hline Sex & $\begin{array}{l}\text { Male } \\
\text { Female }\end{array}$ & $\begin{array}{l}79(59.4) \\
54(40.6)\end{array}$ & $\begin{array}{l}\text { Ref } \\
0.461(0.289-2.157)\end{array}$ & $\begin{array}{l}\text { Ref } \\
0.926(1.0281-1.034)\end{array}$ & 0.496 \\
\hline Residency & $\begin{array}{l}\text { Urban } \\
\text { Rural }\end{array}$ & $\begin{array}{l}85(63.9) \\
48(36.1)\end{array}$ & $2.819(1.708-12.432)$ & $\begin{array}{l}\text { Ref } \\
3.51(1.951-11.430)\end{array}$ & 0.001 \\
\hline Marital & Single & $55(41.4)$ & Ref & Ref & \\
\hline status & $\begin{array}{l}\text { Married } \\
\text { Divorced } \\
\text { Widowed }\end{array}$ & $\begin{array}{l}32(24.1) \\
37(27.8) \\
9(6.8)\end{array}$ & $\begin{array}{l}0.971(0.537-2.013) \\
1.016(0.920-8.690) \\
0.614(0.152-4.916)\end{array}$ & $\begin{array}{l}1.53(0.183-1,8740) \\
1.962(0.427-2.942) \\
0.385(0.089-1.259)\end{array}$ & $\begin{array}{l}0.951 \\
0.008 \\
0.509\end{array}$ \\
\hline $\begin{array}{l}\text { Living } \\
\text { condition }\end{array}$ & $\begin{array}{l}\text { Alone in the house } \\
\text { Alone on the street } \\
\text { With family/friends } \\
\text { Others }\end{array}$ & $\begin{array}{l}62(46.6) \\
9(6.8) \\
48(36.1) \\
14(10.5)\end{array}$ & $\begin{array}{l}\text { Ref } \\
0.418(0.317-3.197) \\
0.752(0.479-2.519) \\
0.163(0.019-3.185)\end{array}$ & $\begin{array}{l}\text { Ref } \\
0.75(0.042-1.017) \\
1.03(0.073-1.079) \\
0.431(0.741-1.658)\end{array}$ & $\begin{array}{l}0.0543 \\
0.193 \\
0.860\end{array}$ \\
\hline
\end{tabular}




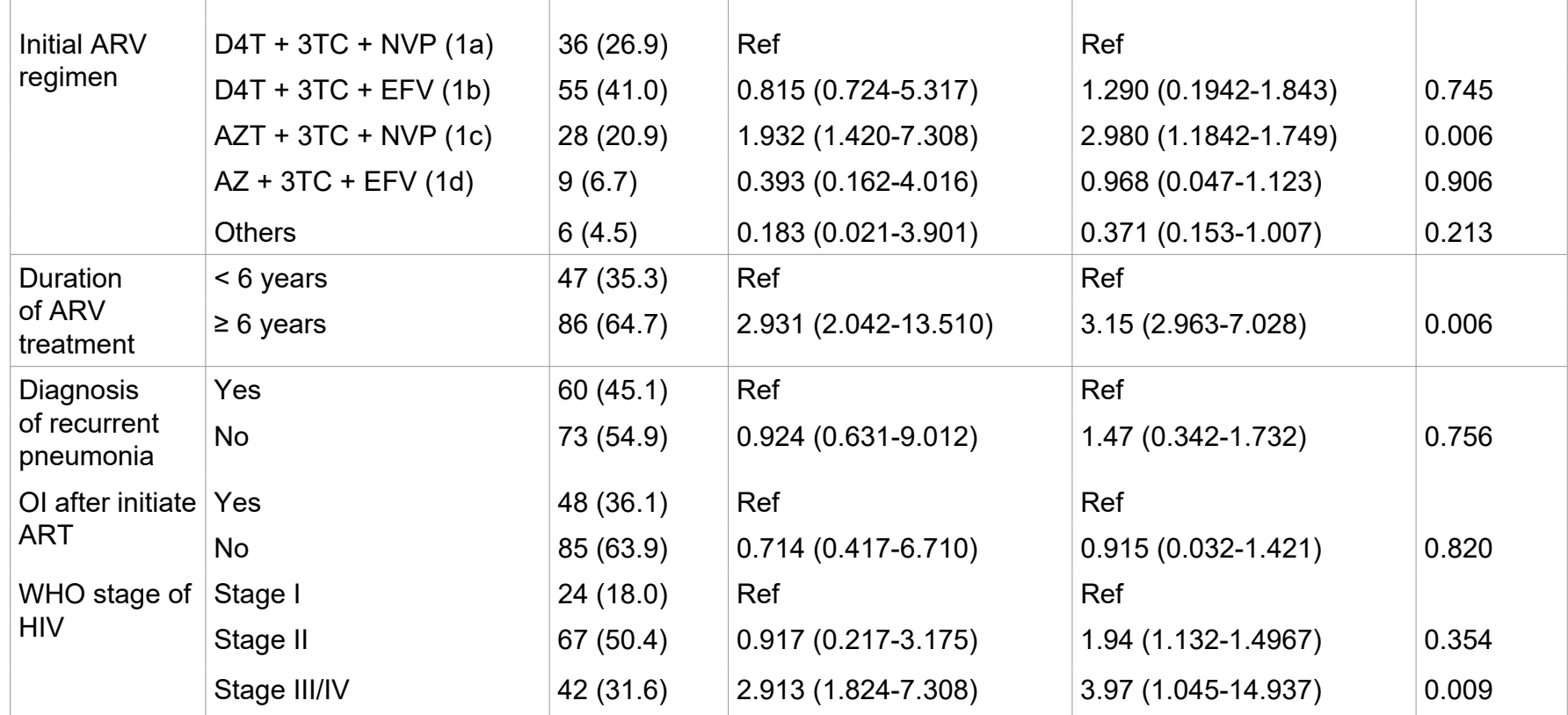

a result of formulary restrictions and extremely diverse complexity of therapeutics regimes such as pills burden an dosing frequency. Our study was lower than the study conducted in United Kingdom 34.0\%, Brazil 74.3\% $[24,25]$. Due to base line characteristics of the sample composed of patients with follow up in public referral services presented a high proportion of individuals with low income and educational level could contribute with a greater occurrence of non-adherence episodes as these individuals may potential present increased vulnerability and difficulties in accessing the services. The current study was in line with the study conducted in Tanzania 31.6\% [26]. Because from all countries in the world those in sub Saharan Africa have the highest rate of HIV/AIDS and non-adherence due to side effects, dosing frequency and route of administration, different opportunistic infections and social stigma.

In our study the mean age of patients were 30-35 years in line with the study conducted in Harar public hospitals [22], Ethiopia which revealed the age of majority respondents were 35 years. This was due to the patients had unprotected sexual intercourse after using alcohol, cigarette and khat which made them to done with copious girls adultery which disclose then HIV/AIDS and at this age patients were not eager to accept the drug due to they believe self-immunity was defeat the infectious disease.

The current survey conducted revealed the magnitude of first line anti-retroviral treatment failure among HIV patients were highest among patient $\geq 42$ years were (AOR: $2.04 ; 95 \% \mathrm{Cl}: 1.0761-5.902 ; \mathrm{P}=0.002$ ) 2 times more likely develop treatment failure than other age category were in line with the study carried out in Harare Central Hospital [22] which showed age $\geq 42$ years were associated with lower odds of virological failure. This was due to most patients at this age had many co-morbid disease such as dementia, Alzheimer's which makes the patients not to take his/her pills as recommended through forgetfulness and patients at this age were desperate about life then not had willing to use the medications due to miss understandings.

The recent study regarding marital status divorced (AOR: $1.962 ; 95 \% \mathrm{Cl}$ : 0.427-2.942; $\mathrm{P}=0.008$ ) 2.9 times more likely develop treatment failure than the left marital status was consistent with the study done in Gondar [27] showed being widowed marital status were more likely develop treatment failure. In our survey the divorced was thought about their marital status kaput rather than other marital status, also don't had access things such as cost of transportation, enough eager to take the medication.

Our study showed ART users who dwelled in rural areas were two times more likely to develop firstline ART failure than those reside rural (AOR: 3.51; 95\% Cl: 1-11.4 30; $\mathrm{P}=0.001) 3.5$ times more likely develop treatment failure than those in lived in urban. Because those who live in the rural area had no enough information about HIV/AIDS impact and its medication usage value, and also they miss the appointment day due no access facility such as road, unavailability of transportation.

The present survey revealed patients whose baseline WHO clinical stages III/IV (AOR: 3.97; 95\% Cl: 1.045-14.937; $P=0.009) 3.9$ times more likely develop treatment failure than baseline WHO clinical stage I and II in line the study conducted in Ethiopia [28] which showed advanced WHO clinical stage was a significant predictor of ART treatment failure as indicated in studies in Ethiopia. The likelihood of treatment failure was 2.4 times higher among patients in advanced clinical stage III/IV as compared to stage I/II in this meta-analysis. Due to at stages III/IV the patients may bedridden and unable to take the pills unless no aid, and the had several opportunistic infection which perhaps restrict 
the patients from oral route of drug administration.

The present study showed HIV/AIDS infected patients who were on $A Z T+3 T C+N V P(1 C)$ at initial ARV regimen follow up (AOR:2.980; 95\% Cl: 1.1842-1.749; $\mathrm{P}=0.006$ ) 3 times more likely develop treatment failure than those who taken others regimen consistent with study conducted at University of Gondar Referral Hospital [29] which revealed the results of this research showed that initial adult regimens such as $D 4 T+3 T C+E F V(P=$ $0.007), A Z T+3 T C+N V P(P=0.025), A Z T+3 T C+E F V(P$ $=0.016), T D F+3 T C+E F V(p=0.009)$ were significantly protective for treatment failure as compared to regimen $A Z T+3 T C+N V P$. This finding was in line with the study done in Ethiopia. In our survey most patients who taken $A Z T+3 T C+N V P$ were interrupt the drug due to the side effects of AZT and NVP which made the patients not comfortable to taken the medication due both medication had severe hepatotoxicity adverse events and headache/dizziness.

\section{Conclusion and Recommendation}

The magnitude of first line anti-retroviral treatment failure among HIV patients was high. The initial regimen for HIV/AIDS infected patients were D4T + 3TC + EFV, and majority of patients were substitute the medication none. Side effects were the major reason that why the patients substitute their regimen. Slightly less than half of respondents weren't have diagnosis of recurrent pneumonia (> 2 episodes), and of patients diagnosed not to have antiretroviral treatment failure. Health care workers should have to educate the patients on how the disease where prevented and controlled and government also implement new drafts on the drug efficiency.

\section{Ethical Approval and Considerations}

The study protocol was approved by SWAN diagnostic pharmaceutical importer. All participants requiring medical attention and those diagnosed with first line ART failure privacy and behind the scenes were ensured during data collection process. Participant names were not used at the time of data collection and all other personnel information kept anonymously.

\section{Acknowledgments}

We thankful to the patients for their through-going time to brought us response and data collectors.

\section{References}

1. Federal Ministry of Health (2017) National guidelines for comprehensive HIV prevention, care and treatment.

2. Bain L, Nkoke EC, Noubia JJN (2017) UNAIDS 90-9090 targets to end the AIDS epidemic by 2020 are not realistic: Comment on"Can the UNAIDS 90-90-90 target be achieved? A systematic analysis of national HIV treatment cascades". BMJ global health 2: e000227.

3. Liao L, Xing H, Su B, Wang Z, Ruan Y, et al. (2013) Impact of HIV drug resistance on virologic and immunologic failure and mortality in a cohort of patients on antiretroviral therapy in China. AIDS 27:1815-1824.

4. Cozzi-Lepri A, Phillips AN, Clotet B, Mocroft A, Ruiz L, et al. (2008) Detection of HIV drug resistance during antiretroviral treatment and clinical progression in a large European cohort study. AIDS 22: 2187-2198.

5. James T, Heiner G, John C, Angela O, Frank M, et al. (2006) Risk factors inflencing HIV infection incidence in a rural African population a nested case-control study. J Infect Dis 193: 458-466.

6. Asfaw AB, Nigusie A, Shewanow T, Gudina EK, Getnet M, et al. (2020) Determinants of first line antiretroviral treatment failure among patients on highly active antiretroviral therapy in selected public Hospitals Jimma, Southwest Ethiopia a case control study. Science PG 4:13-14.

7. WHO (2016) The use of antiretroviral drugs for treating and preventing HIV infection. Re commendations for a Public Health Approach; Geneva, Switzerland.

8. WHO (2018) Antiretroviral therapy coverage data and estimates by WHO region 2018.

9. Babo YD, Alemie GA, Fentaye FW (2017) Predictors of first-line antiretroviral therapy failure amongst HIV-infected adult clients at Woldia Hospital, North east Ethiopia. PLoS One 12: 1-19.

10. Keiser $\mathrm{O}$, Tweya $\mathrm{H}$,Braitstein $\mathrm{P}$, Dabis $\mathrm{F}$, MacPhail $\mathrm{P}$, et al. (2010) Mortality after failure of antiretroviral therapy in subsaharan Africa. Trop Med Int Health 15: 251-258.

11. Aachen HG (2018) HIV Germany Medizin Fokus Verlag: Boston MA (USA).

12. Bokretsion GB, Endalkachew N, Getachew KA (2017) HIV/ AIDS treatment failure and its determinant factors among first line HAART patients at Felege Hiwot referral hospital, Bahir Dar, Northwest Ethiopia. J AIDS Clin Res 8: 4.

13. Melsew YA, Terefe MW, Tessema GA, Ayele TA (2013) Rate of immunological failure and its predictors among patients on highly active antiretroviral therapy at Debre markos hospital, Northwest Ethiopia: A retrospective follow up study. J AIDS Clin Res 4: 211

14. Renaud-Théry F, Duncombe C, Kerr S, Thierry S, Perriëns $\mathrm{J}$ (2010) Adult anti retro viral therapy in resource limited settings: A systematic review of first-line failure and attrition rates. 17th Conference on Retroviruses and Opportunistic Infections, San Francisco.

15. Yimer Y, Yalew AW (2015) Magnitude and predictors of antiretroviral treat ment (ART) failure in private health facilities in Addis Ababa, Ethiopia. PLoS One 10: e0126026.

16. Tsegaye AT, Wubshet M, Awoke T, Addis Alene K (2016) Predictors of treatment failure on second-line antiretroviral therapy among adults in Northwest Ethiopia: A multi centre retrospective follow-up study. BMJ Open 6: e012537.

17. Haile D, Takele A, Gashaw K, Demelash H, Nigatu D (2016) Predictors of treatment failure among adult antiretroviral treatment ( ART ) clients in bale zone hospitals, south eastern Ethiopia. PLoS One 11: 2-8.

18. d'Arminio Monforte A, Lepri AC, Rezza G, Pezzotti P, Antinori A, et al. (2000) Insights into the reasons for discontinuation of the fist highly active antiretroviral therapy (HAART) regimen in a cohort of antiretroviral naïve patients. I.CO.N.A. Study Group. Italian cohort of antiretroviral-naïve patients. AIDS 14: 499-507.

19. Mutevedzi PC, Rodger AJ, Newell ML (2011) Association of age with mortality and virological and immunological 
response to antiretroviral therapy in rural South African adults. PLoS One 6: e2179.

20. Petersen ML, der Laan MJV, Napravnik S, Eron JJ, Moore $\mathrm{RD}$, et al. (2008) Long-term consequences of the delay between virologic failure of highly active antiretroviral therapy and regimen modification. AIDS 22: 2097-2106.

21. Ayalew MB, Kumilachew D, Belay A, Getu S, Teju D, et al. (2016) First-line antiretroviral treatment failure and associated factors in HIV patients at the University of Gondar Teaching Hospital, Gondar, Northwest Ethiopia. HIVIAIDS (Auckl) 8: 141-146.

22. Feleke R, Geda B, Roba KT, Weldegebreal F (2020) Magnitude of antiretroviral treatment failure and associated factors among adult HIV-positive patients in Harar public hospitals, Eastern Ethiopia. SAGE Open Medicine 8: 1-7.

23. Bezabih MY, Beyene F, Bezabhe WM (2019) Factors associated with first-line antiretroviral treatment failure in adult HIV positive patients: A case- control study from Ethiopia. BMC Infectious Diseases 19: 537.

24. Khienprasit N, Chaiwarith R, Sirisanthana T, Supparatpinyo $\mathrm{K}$ (2011) Incidence and risk factors of antiretroviral treatment failure in treatment-naïve HIV-infected patients at Chiang Mai University Hospital, Thailand. AIDS Res Ther 8: 42.

25. Kamya MR, Mayanja-Kizza H, Kambugu A, Bakeera-
Kitaka S, Semitala F, et al. (2007) Predictors of long-term viral failure among Brazil children and adults treated with antiretroviral therapy. JAIDS J Acquir Immune Defic Syndr 46: 187-193.

26. Project PHIA (2017) Tanzania HIV impact survey 20162017. New York.

27. Agezew T, Tadesse A, Derseh L, Yimer M (2019) Incidence and predictors of first line anti-retroviral therapy failure among adults receiving HIV care in North West Ethiopia: A hospital-based follow-up study. J Infect Dis Epide Miol 5: 072.

28. Assemie MA, Alene M, Ketema DB, Mulatu S (2019) Treatment failure and associated factors among first line patients on highly active antiretroviral therapy in Ethiopia: A systematic review and meta-analysis. Global Health Res earch and Policy 4: 32.

29. Ayele G, Tessema B, Amsalu A, Ferede G, Yisma G (2018) Prevalence and associated factors of treatment failure among HIVIAIDS patients on HAART attending University of Gondar Referral Hospital Northwest Ethiopia. BMC Immunology 19: 37. 